\title{
Laparoscopic Resection of Primary Tumor with Synchronous Conventional Resection of Liver Metastases in Patients with Stage 4 Colorectal Cancer: A Retrospective Analysis
}

\section{Evre 4 Kolorektal Kanserli Hastalarda Primer Tümörün Laparoskopik, Karaciğer Metastazlarının Konvansiyonel Olarak Senkron Rezeksiyonu: Retrospektif bir Analiz}

\author{
(1) Nuri Okkabaz1, (1) Mustafa C. Haksal2, (1) Mustafa Öncel2 \\ 1 İstanbul Bağcılar Tranining and Research Hospital, Clinic of General Surgery, İstanbul, Turkey \\ 2İstanbul Medipol University Faculty of Medicine, Department of General Surgery, İstanbul, Turkey
}

\section{IIIIIIII| ABSTRACT}

Aim: Aim of this study is to analyze the short and long term results of laparoscopic colorectal cancer resection with synchronous conventional resection of liver metastasis.

Method: All cases operated on synchronous colorectal cancer and liver metastasis between 2009 and 2017 were retrospectively retrieved from a prospective database. Three and more liver segment resection was considered as major resection. Demographics, patient characteristics, operative and postoperative findings and survival were analyzed.

Results: A total of 35 patients [23 (65.7\%) male, median age: 56 (34-79)] was included to the study. The most common primary tumor localization was rectum $(\mathrm{n}=20,57.1 \%)$. Neoadjuvant chemoradiotherapy and chemotherapy was applied in 15 (75\%) and 14 (40\%) cases, respectively. Major, minor resection or only ablative therapy performance was 12 (34.3\%), 19 (54.3\%) and 4 (11.4\%), respectively, but 13 (37.1\%) cases received both resection and ablative therapy. Mean operation time was 307.8 \pm 103.6 minutes and estimated blood loss was 300 (10-2200) cc. Blood transfusion was needed in 15 (42.9\%) cases. Length of stay was 7 (4-17) days. Eleven complications developed in 10 (28.6\%) cases, but none required re-operation. A patient (2.9\%) underwent laparoscopic low anterior resection with major hepatectomy and radiofrequency ablation was deceased in postoperative $11^{\text {th }}$ day due to liver failure and subsequent multiorgan failure. Three, 5, 7 and 9 -year survival rates was $63 \%, 35 \%, 35 \%$, and $35 \%$.

Conclusion: Laparoscopic colorectal resection with synchronous conventional liver resection in patients with metastatic colorectal cancer is safe and feasible. Long term survival rates are acceptable.

Keywords: Laparoscopy, liver metastasis, colorectal cancer, synchronous tumor

\section{|IIIIIIII| ÖZ}

Amaç: $\mathrm{Bu}$ çalışmanın amacı karaciğer metastazlı kolorektal kanserli kolorektal tümörün laparoskopik, karaciğer metastaz cerrahisinin ise açık yöntemle tamamlandığı hastalarda kısa ve uzun dönem sonuçları irdelemektir.

Yöntem: Prospektif olarak bilgi girişi yapılan bir veri bankasından 2009-2017 yılları arasında senkron metastaz cerrahisi uygulanan ve laparoskopik kolorektal rezeksiyon yapılan hastalar derlendi. $\geq 3$ segment rezeksiyonu majör rezeksiyon olarak nitelendirildi. Demografi ve hastalara ait verilerle, ameliyat ve ameliyat sonrası bilgiler ve sağkalım incelendi.

Bulgular: Otuz beş hasta [23 (\%65,7) erkek, ortanca 56,0 (34-79) yaş] bulundu. En sık yerleşim yeri rektumdu (n=20, \%57,1). Neoadjuvant kemoradyoterapi ve/veya kemoterapi alan olgu sayısı 15 (\%75) ve 14 (\%40) idi. Majör, minör rezeksiyon veya sadece ablasyon uygulaması sırasıyla $12(\% 34,3), 19(\% 54,3)$ ve $4(\% 11,4)$ hastada yapıldı. Ayrıca $13(\% 37,1)$ hastaya hem rezeksiyon ve hem de ablasyon uygulandı. Ortalama operasyon

Address for Correspondence/Yazışma Adresi: Nuri Okkabaz MD,

İstanbul Bağcilar Tranining and Research Hospital, Clinic of General Surgery, İstanbul, Turkey

Phone: +90 5063438750 E-mail: n_okkabaz@yahoo.com ORCID ID: orcid.org/0000-0001-8962-2057

Received/Geliş Tarihi: 16.07.2018 Accepted/Kabul Tarihi: 27.12.2018

${ }^{\circ}$ Copyright 2019 by Turkish Society of Colon and Rectal Surgery

Turkish Journal of Colorectal Disease published by Galenos Publishing House. 
süresi 307,8 103,6 dakikaydı ve kan kaybı miktarı 300 (10-2200) cc idi. On beş (\%42,9) hastada kan transfüzyonu gerekti. Hastalar 7 (4-17) günde taburcu edildiler. Toplam 10 (\%28,6) hastada en az bir, toplamda ise 11 komplikasyon geliști. Hiçbir hastaya bu komplikasyonlara bağlı re-operasyon gerekmedi. Laparoskopik aşağı anterior rezeksiyon, majör hepatektomi ve radyofrekans ablasyon uygulanan bir olgu (\%2,9) operasyondan 11 gün sonra karaciğer yetmezliğine ikincil gelişen çoklu organ yetmezliğine bağlı olarak kaybedildi. Hastalarda 3, 5, 7 ve 9 yıllık sağkalım oranları \%63, $\% 35, \% 35$ ve $\% 35$ idi.

Sonuç: Karaciğer metastazlı kolorektal kanserlerde, kolorektal kanserin laparoskopik, karaciğer metastaz cerrahisinin ise açık yöntemle uygulanabilir ve güvenilir bir yöntemdir. Uzun dönem sağkalım kabul edilebilir sınırlardadır.

Anahtar Kelimeler: Laparoskopi, karaciğer metastaz, kolorektal kanser, senkron tümör

\section{Introduction}

Colorectal cancer (CRC) is one of the major causes of malignancy-related deaths and approximately one million people are diagnosed with CRC every year in Western societies. ${ }^{1}$ Approximately $15-25 \%$ of these patients have synchronous liver metastasis at the time of diagnosis and the potential curing is the radical resection of the primary tumor and liver metastasis. ${ }^{2}$ The most appropriate treatment strategy for CRC patients presenting with liver metastasis is controversial and many factors, including the burden of disease and the general condition of the patient, influence the decision of treatment. ${ }^{3}$ Although synchronous removal of primary and hepatic tumors has the potential to increase the likelihood of complications and mortality, some studies have shown that combined applications are safe and effective even if major hepatectomies are administered. ${ }^{4,5,6}$

Numerous prospective randomized studies have shown that laparoscopic surgery for CRCs is safe. ${ }^{7,8}$ Although multiinstitutional studies have shown that minimally invasive methods can be used in liver metastasis surgery, the results of the only prospective randomized study initiated in this regard have not been established yet. ${ }^{9,10}$ On the other hand, it is not known whether laparoscopic resection of primary tumor is advantageous when liver metastasis is conventionally removed. A study of 40 patients with comparative cases has shown that laparoscopic technique may provide an advantage in blood loss and return of bowel movements. ${ }^{11}$ This study concludes that this issue should be examined in more detail. The aim of this study is to retrospectively examine the patients who underwent simultaneous liver metastasectomy during laparoscopic CRC resection.

\section{Materials and Methods}

All patients included in the study were retrospectively collected from a database that had been prospectively entered since 2002. This database includes patients who were operated at Kartal Training and Research Hospital General Surgery Clinic between 2002-2012 and at İstanbul Medipol University, General Surgery Department, Colorectal\&Oncology Surgery Department after 2012 by a single surgeon (MO) in İstanbul Medipol University, General Surgery Department, Colorectal\&Oncology Surgery Department. Since 2013, liver surgery has been performed by another team that works specifically for hepatobiliary surgery. Prior to compiling the data, the İstanbul Medipol University Ethics Committee (10840098-604.01.01E.47598) approved the study. All patients with metastatic CRC who were operated on synchronously were included in the study. During the data collection, the following cases were excluded: only those treated for metastasis (including those who were operated progressively, including the "liver first" approach), both the primary tumor and the metastasis were operated by open or laparoscopic techniques, and the primary tumor was operated by a robot-assisted operation, patients with recurrent CRC associated with liver metastasis, and carcinomatosis or other reasons, and who did not undergo curative treatment for CRC and/or liver metastasis.

\section{Preoperative}

Evaluation and decision-making in all patients were performed in a multidisciplinary council. Local staging was performed with abdominal computed tomography (CT) for colon cancer and magnetic resonance imaging (MRI) for rectal cancers. Metastatic investigations were performed with upper abdominal MRI, lung CT and positron emission scintigraphy/CT. Neoadjuvant radiotherapy was applied in patients with T3-4 and/or node positive middle-lower rectal cancer. Neoadjuvant chemotherapy decision was given in some patients with the decision of multidisciplinary council, especially in cases with higher liver tumor burden. These patients were re-staged after a metastatic chemotherapy regimen.

\section{Surgical Technique}

All patients underwent surgery beginning with CRC. The operation was completed with total mesorectal excision in rectal tumors, complete mesocolic excision in colon tumors (since 2012 in the right colon), high ligation of the vessel(s) and paying attention to the integrity of the specimen. In patients undergoing inferoanterior or low anterior resection, the most appropriate incision was made for liver surgery after stapler firing. Mobilization of splenic flexure and removal of the specimen from the abdomen were 
completed by this incision. The anastomosis was completed intracorporally after re-insufflation of the abdomen and under direct observation from the incision in some anterior resection patients. In the right colon tumors, the incision was used to take out of the specimen as well as the extracorporeal ileo-colonic anastomosis.

Before the resection, an experienced radiologist reevaluated the liver by intraoperative ultrasound and the operation plan was changed if there was a different finding according to the preoperative data. The same expert performed the ablative procedure (radiofrequency or microwave) with the aid of intraoperative ultrasound radiofrequency or microwave. Liver resection was performed using Habip ${ }^{\circledR}$ 4X device (AngioDynamics, Latham, NY) (mostly before 2012) or by conventional methods. If necessary, the surgical margin was evaluated with frozen section. Pringle maneuver was performed in both techniques when necessary. Postoperative care was not different from standard CRC surgery. After pathological examination, all patients were re-evaluated in the multidisciplinary council for the next treatment/followup approach.

\section{Statistical Analysis}

Patient and disease-related variables (demographic information, presence of previous abdominal surgery, comorbidity, American Anesthesia Association (ASA) score, tumor localization, lung metastasis in addition to the liver), whether or not received neoadjuvant chemotherapy and/or radiotherapy, data on the operation and pathology (type of operation for CRC, type of incision, need for conversion, if necessary, number of liver metastases, maximum metastasis size, type of liver resection, ablation procedure, amount of bleeding, necessity of blood replacement during and/or after the operation, additional organ resection, tumor grade, $\mathrm{T}$ and $\mathrm{N}$ stage, the number of harvested lymph nodes, the number of positive lymph nodes, presence of vascular and perineural invasion), post-operative process (complications, hospitalization duration of stay, 30-day mortality) and survival. Tumors at a distance of $\leq 15 \mathrm{~cm}$ from the dentate line were accepted as rectum tumors, and tumors at $\leq 12$ $\mathrm{cm}$ distance were accepted as middle-lower rectal cancers. Resections larger than 3 segments in the liver were called major resection. Data were reported as mean (standard deviation) or median (range), rates were reported with percentages. Survival was analyzed with Kaplan-Meier test.

\section{Results}

Thirty-five patients [23 (\% 65,7) male, median age: 56,0 (3479)] whose primary tumor was operated on by laparoscopic and metastasis by open method, synchronously between the years of 2009-2017 were examined. Ten (28.6\%) patients had previous abdominal incisions [McBurney $(\mathrm{n}=7,22.9 \%)$, subcostal $(\mathrm{n}=2,5.7 \%)$ and Pfannelstiel $(\mathrm{n}=1,2.9 \%)]$ of 10 patients $(28.6 \%)$ had previous operations.]) Thirteen (37.1\%) patients had comorbidity [hypertension ( $\mathrm{n}=9$, $25.7 \%)$, type II diabetes mellitus [n=7, 20.0\%], coronary artery disease $(n=4,11 \%, 4)$, congestive heart failure $(\mathrm{n}=2,5.7 \%)$ and previous malignancy $(\mathrm{n}=1,2.9 \%)]$. The distribution of the patients according to ASA score was as follows: $1(\mathrm{n}=11,31.4 \%), 2(\mathrm{n}=17,48.6 \%)$ and $3(\mathrm{n}=7,20 \%)$.

Table 1. Surgical procedures for local and liver metastasis with primary tumor localization

\begin{tabular}{|c|c|c|c|c|}
\hline Primary tumor localization & Primary tumor surgery & Major/minor* & Liver resection & $\begin{array}{l}\text { Ablation of the } \\
\text { liver }\end{array}$ \\
\hline Cecum $(n=4,11.4 \%)$ & $\begin{array}{l}\text { Right hemicolectomy }(\mathrm{n}=3) \\
\text { Extended right hemicolectomy }(\mathrm{n}=1)\end{array}$ & $0 / 3(75.0 \%)$ & Metastasectomy $(\mathrm{n}=3)$ & $\mathrm{n}=1$ \\
\hline Ascending colon ( $\mathrm{n}=1,2.9 \%)$ & Right hemicolectomy & $1(100 \%) / 0$ & Segmentectomy $(n=3)$ & None \\
\hline Transverse colon $(n=2,5.7 \%)$ & Extended right hemicolectomy & $1(50.0 \%) / 1(50.0 \%)$ & $\begin{array}{l}\text { Segmentectomy }(n=3) \\
\text { Metastasectomy }(n=1)\end{array}$ & $\mathrm{n}=2$ \\
\hline Splenic flexure (n=1, 2.9\%) & $(n=3)$ & $1(\% 100) / 0$ & $\begin{array}{l}\text { Segmentectomy }(n=3) \\
\text { Metastasectomy }(n=3)\end{array}$ & None \\
\hline Sigmoid colon $(n=5,14.3 \%)$ & oterior recestion & $2(40.0 \%) / 3(60.0 \%)$ & $\begin{array}{l}\text { Segmentectomy }(n=14) \\
\text { Metastazektomi }(n=2)\end{array}$ & $\mathrm{n}=3$ \\
\hline Rectosigmoid $(n=2,5,7 \%)$ & Anterior resection & $1(50.0 \%) / 1(50.0 \%)$ & $\begin{array}{l}\text { Segmentectomy }(n=4) \\
\text { Metastasectomy }(n=2)\end{array}$ & $\mathrm{n}=1$ \\
\hline Rectum $(\mathrm{n}=20,57.1 \%)$ & $\begin{array}{l}\text { Low anterior resection }(\mathrm{n}=17) \\
\text { Hartmann }(\mathrm{n}=1) \\
\text { Abdominoperineal resection }(\mathrm{n}=2)\end{array}$ & $6(30.0 \%) / 12(60.0 \%)$ & $\begin{array}{l}\text { Segmentectomy }(n=24) \\
\text { Metastasectomy }(n=1)\end{array}$ & $\mathrm{n}=8$ \\
\hline
\end{tabular}

(*Resections more than three segments are classified as major and less are classified as minor) 
The most common location was rectum $(n=20,57 \cdot 1 \%)$. Fifteen (75\%) patients with rectal cancer received neoadjuvant short-term radiotherapy. Preoperative chemotherapy was given to 14 patients ( $40 \%$ ) due to liver tumor burden. The localization of primary disease, techniques applied to these sites, accompanying liver surgical resection procedure and ablation procedures are presented in Table 1. In total, 12 (34.3\%) patients underwent major resection, 20 (57.1\%) patients underwent minor resection, and 3 (8.6\%) underwent only ablation. In addition, 13 (37.1\%) patients underwent both resection and ablation at the same session.

None of the patients required additional trocar application during laparoscopy. The incisions that were planned for liver resection were: subcostal $(\mathrm{n}=31,88.6 \%)$, chevron $(\mathrm{n}=3,8.6 \%)$, midline and transverse $(\mathrm{n}=1,2.9 \%)$. One

Table 2. Complications after surgery

\begin{tabular}{|c|c|}
\hline Complications* & \\
\hline Surgical site infection & $3(8.6)$ \\
\hline Wound infection & $3(8.6)$ \\
\hline Abdominal abscess & $1(2.9)$ \\
\hline Anastomotic leakage ${ }^{* *}$ & $1(3.2)$ \\
\hline Urinary retention & $1(2.9)$ \\
\hline Non-surgical complications & $3(8.9)$ \\
\hline Bile fistula & $1(2.9)$ \\
\hline Biliary stasis & $1(2.9)$ \\
\hline Total patient* & $10(28.6)$ \\
\hline $\begin{array}{l}\text { * Since more than one com } \\
\text { number of complications is hi } \\
\text { complications. } \\
\text { **Patients who underwent Har } \\
\text { resection were excluded, an } \\
\text { considered. }\end{array}$ & $\begin{array}{l}\text { is seen in some cases, the } \\
\text { the number of patients with } \\
\text { cedure and abdominoperineal } \\
\text { ases with anastomosis were }\end{array}$ \\
\hline
\end{tabular}

Table 3. Pathological examination results

\begin{tabular}{|c|c|}
\hline Variables & Results \\
\hline T stage (T1/T2/T3/T4) & $\begin{array}{l}1(\% 2.9) / 3(\% 8.6) / 26 \\
(\% 74.3) / 5(\% 14.3)\end{array}$ \\
\hline N stage (N0/N1/N2) & $\begin{array}{l}11(\% 31.4) / 14(\% 40.0) / 10 \\
(\% 28.6)\end{array}$ \\
\hline Harvested lymph node & $21(2-70)$ \\
\hline Malignant lymph node & $2(0-13)$ \\
\hline $\begin{array}{l}\text { Differentiation (poor/moderate/ } \\
\text { well/unknown) }\end{array}$ & $\begin{array}{l}2(5.7 \%) / 12(34.3 \%) / 20 \\
(57.1 \%) / 1(2.9 \%)\end{array}$ \\
\hline The presence of vascular invasion & $13(37.1 \%)$ \\
\hline $\begin{array}{l}\text { The presence of perineural } \\
\text { invasion }\end{array}$ & $19(54.3 \%)$ \\
\hline
\end{tabular}

patient $(2.9 \%)$ converted to open surgery because of lack of exploration due to intestinal dilatation. Median 1 (1-4) additional liver metastases were detected in patients after ultrasonography (USG) and the largest metastasis length was $2 \mathrm{~cm}$. Two patients (5.7\%) required additional organ resection (ovary in 1 patient and abdominal wall in 1 patient). The mean ( \pm standard deviation) operation time was $307.8 \pm 103.6$ minutes and the median (range) blood loss amount was 300 (10-2200) cc. Fifteen (42.9\%) patients required blood transfusion during perioperative period. The patients were discharged on median (range) 7 (4-17) days. In $2(5.7 \%)$ patients, lung metastasis was present in addition to the liver and these metastases were operated on at subsequent surgery (s). At least one complication occurred in total 10 (28.6\%) patients and 11 complications in total (Table 2). No patient required re-operation due to these complications. One case $(2.9 \%)$ who underwent laparoscopic low anterior resection, major hepatectomy and radiofrequency ablation died due to multiple organ failure secondary to liver failure 11 days after the operation. The results of the pathological examinations of the extracted specimens are presented in Table 3. Surgical margin positivity was not observed in CRC resections, but in $3(8.6 \%)$ patients at liver resection site. Overall survival in patients is presented in Figure 2.

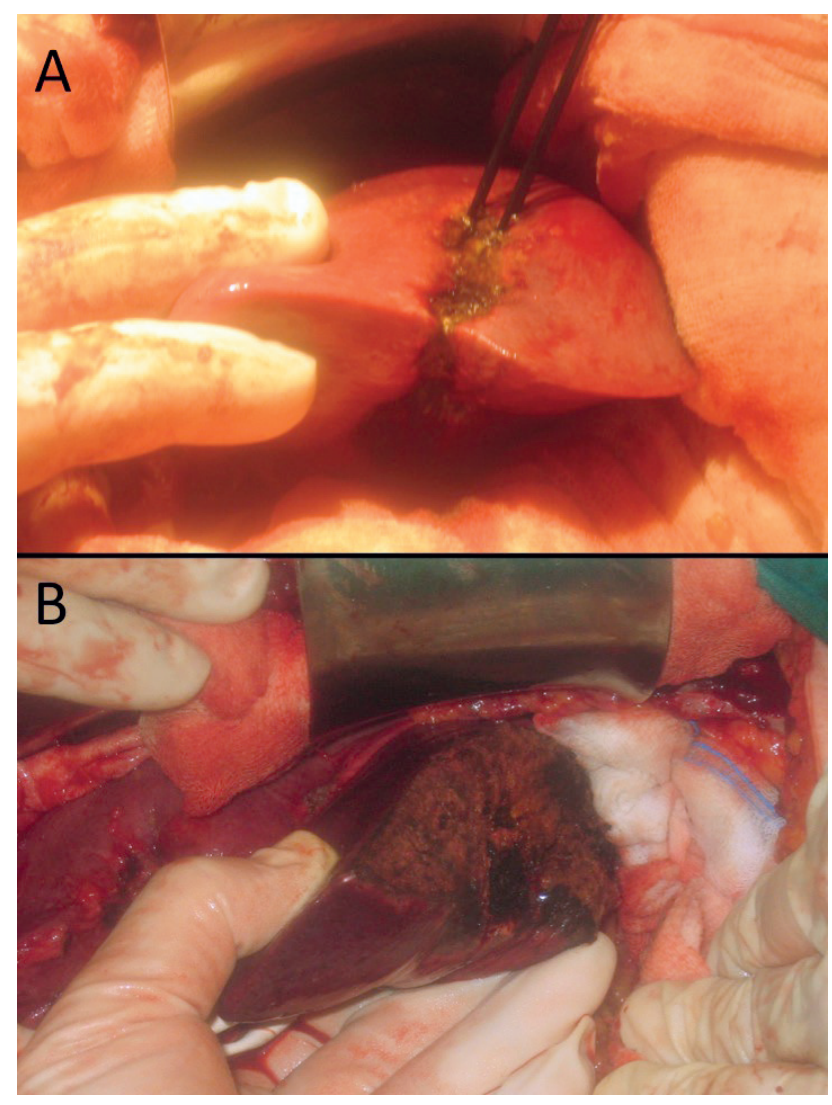

Figure 1. Liver segment 2 and 3 resection (A), and view after resection (B) 


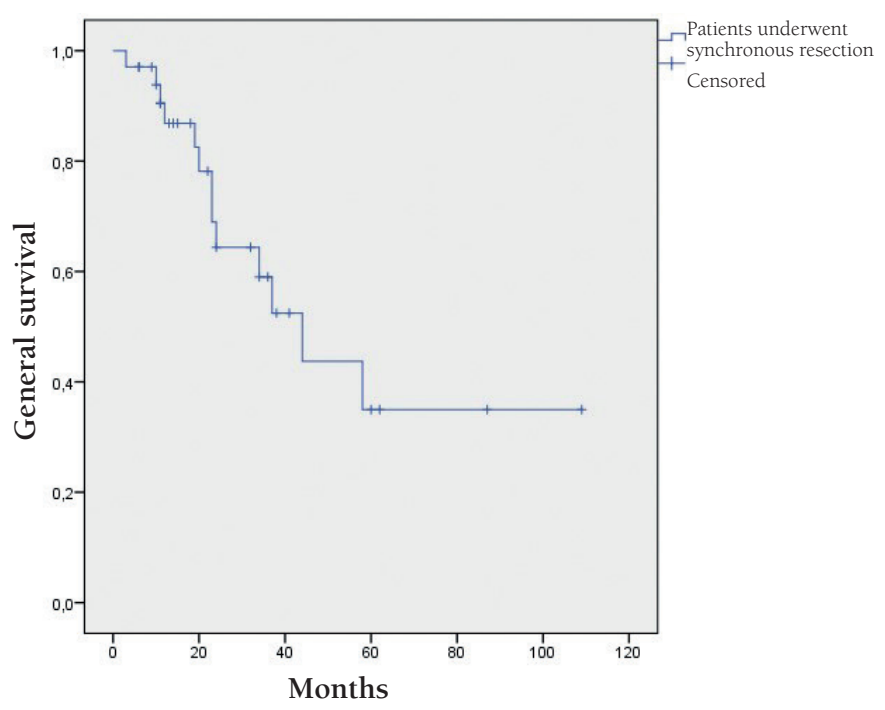

Figure 2. Kaplan-Meier analysis shows that survival rates of 3, 5, 7 and 9 years in colorectal cancer patients who were applied synchronous liver metastasectomy were 63\%, 35\%, 35\% and 35\%

\section{Discussion}

In CRCs, they may present as metastatic at the time of diagnosis. Surgical resection can be considered as an option even in patients with liver and/or lung metastases. In this study, we present cases in which combined liver metastasis surgery and colorectal surgery are obtained from a single database. Many studies have shown that such synchronous procedures are feasible and safe..$^{12,13,14}$ A systemic review examining the same subject highlights the fact that even the major hepatectomies can be safely performed in synchronous procedures with appropriate patient selection competent surgical technique. ${ }^{3}$ The main difference of the present study is that the colorectal procedure is performed laparoscopically. In these patients, especially if the primary tumor is localized to the lower abdominal quadrants, performing laparoscopic surgery may provide a theoretical benefit as it reduces the incision size. However, there is no comparative analysis of colorectal surgery by laparoscopic or open method. In a similar study, Akiyoshi et al. ${ }^{12}$ published a series of 10 cases in which the sigmoid or rectum was removed by laparoscopy and synchronous liver resection by open method and argued that this method was feasible and safe. In another study, Bretagnol et al. ${ }^{13}$ presented a series of large surgeries including right hemicolectomy in 7 cases. After laparoscopic surgery, it is possible to complete liver surgery by laparoscopic method. Retrospective analysis of laparoscopic or open surgery reveals that the early standard advantages (reduction of blood loss, early onset of bowel movements) of laparoscopy also apply to this type of surgery. ${ }^{1,11,14}$ However, intraoperative USG is more difficult to perform in laparoscopic procedures in liver metastases.
On the other hand, intraoperative USG is an important examination for the detection of new lesions and the importance of ablation therapy. In a study done in our group, intraoperative USG changed the operation strategy in some of the patients. ${ }^{15}$ Due to this restriction, according to our thoughts and clinical approach, laparoscopic liver metastasis surgery should not be performed without seeing the results of the ongoing prospective randomized study. ${ }^{10}$ The fact that the patients presented in the study were mostly sigmoid and rectal cancer increases the importance of laparoscopic colorectal surgery in these cases. Because it is possible to reach both the primary lesion and the liver with a relatively short incision in a tumor located in the ascending colon, more distal tumors require longer or even separate incisions. In our opinion, this approach is most useful in patients with sigmoid or rectum primary. Decrease in incision length may be a step to perform more major procedures in the liver, as there are such cases in this series. Laparoscopic removal of CRC may affect intraoperative and early postoperative outcomes in these patients positively or negatively. One study showed that total laparoscopic procedure significantly prolonged operation time compared to open surgery. ${ }^{1}$ Since there is no comparative analysis, there is no clear data on this subject, but the shortening of the abdominal incision can keep this time in a reasonable way by eliminating the time taken for the opening and closing of the abdomen. As a matter of fact, the operation time in the series presented is similar to the time of open surgery in the literature. ${ }^{1}$ In the recent study, there was no conversion to open surgery. This also shortens the length of hospital stay. Median hospital stay in this study was 7 days. Complication rates of up to $50 \%$ in synchronous procedures are reported. ${ }^{11,14}$ In the presented series, this rate was reasonable, below 30\% and did not require reoperation. The only mortality in the series was due to liver failure. Finally, Kaplan-Meier analysis shows that long-term survival in patients is acceptable and comparable to the literature. ${ }^{1,3}$ These findings suggest that open liver procedures accompanying laparoscopic colorectal surgery are feasible and safe.

One of the points underlined in this study is the importance of multidisciplinary approach in the presence of cancer, especially metastatic disease. In all patients presented in this study, the decision of surgery was taken in multidisciplinary councils with the significance of the literature. ${ }^{1,3,12}$ Similarly, all of the colorectal procedures and the majority of surgical procedures for the liver were applied by surgeons who were specific in these subjects. In all cases, intraoperative USG and ablation procedures were completed by experienced radiology teams.

The study had specific limitations. The main problem is the retrospective data collection and the single-arm study design. On the other hand, the inclusion of both right colon 
and sigmoid and even rectal cancers leads to a heterogeneity between the data. Lastly, the inclusion of cases over a long period time has led to many different applications, especially oncological treatment options. On the other hand, the fact that a single colorectal team manages the series and the number of patients is significantly higher compared to similar studies in the literature still makes the study valuable.

In summary, this retrospective analysis shows that laparoscopic CRC surgery and open liver surgery can be performed in CRCs with liver metastatis. This method is a reliable method since it can reveal advantages in terms of early postoperative results. Long-term results are acceptable. All procedures applied to people in the study comply with the ethical standards of institutional and national research boards, the 1964 Declaration of Helsinki and the ameliorative principles published thereafter. No written approval is required in such studies.

\section{Ethics}

Ethics Committee Approval: The study was approved by the İstanbul Medipol University Ethics Committee (approval number: 10840098-604.01.01-E.47598).

Informed Consent: Retrospective study.

Peer-review: Externally peer-reviewed.

\section{Authoring Contributions}

Surgical and Medical Application: M.O., Concept: N.O., M.O., Design: M.H., M.O., Data Collection or Processing: N.O., M.H., Analysis or Interpretation: N.O., M.H., M.O., Literature Search: M.H., M.O., Written: N.O., M.O.

Conflict of Interest: No conflict of interest was declared by the authors.

Financial Disclosure: The authors declared that this study received no financial support.

\section{References}

1. Ratti M, Catena M, Di Palo S, Staudacher C, Aldrighetti. Impact of totally laparoscopic combined management of colorectal cancer with synchronous hepatic metastases on severity of complications: a propensity-score-based analysis. Surg Endosc 2016;30:4934-4945.

2. Pulitano C, Castillo F, Aldrighetti L, Bodingbauer M, Parks RW, Ferla G, Wigmore SJ, Garden OJ. What defines 'cure' after liver resection for colorectal metastases? Results after 10 years of follow-up HPB (Oxford) 2010;12:244-249.

3. Lupinacci RM, Andraus W, De Paiva Haddad LB, Carneiro LA, Herman P. Simultaneous laparoscopic resection of primary colorectal cancer and associated liver metastases: a systematic review. Tech Coloproctol 2014;18:129-135.

4. Bolton JS, Fuhrman GM. Survival after resection of multiple bilobar hepatic metastases from colorectal carcinoma. Ann Surg 2000;231:743-751.

5. Reddy SK, Pawlik TM, Zorzi D, Gleisner AN. Simultaneous resections of colorectal cancer and synchronous liver metastases: a multi-institutional analysis. Ann Surg Oncol 2007;14:3481-3491.

6. Capussotti L, Ferrero A, Vigano` L, Ribero D, Lo Tesoriere R, Polastri. Major liver resections synchronous with colorectal surgery. Ann Surg Oncol 2007;14:195-201.

7. Clinical Outcomes of Surgical Therapy Study Group. A comparison of laparoscopically assisted and open colectomy for colon cancer. N Eng J Med 2004;350:2050-2059.

8. Jayne DG, Guillou PJ, Thorpe H, Quirke P, Copeland J, Smith AM, Heath RM, Brown JM; UK MRC CLASICC Trial Group. Randomized trial of laparoscopic-assisted resection of colorectal carcinoma: 3-year results of the UK MRC CLASICC Trial Group. J Clin Oncol 2007;25:3061-3068.

9. Nguyen KT, Laurent A, Dagher I, Geller DA. Minimally invasive liver resection for metastatic colorectal cancer: a multi-institutional, international report of safety, feasibility, and early outcomes. Ann Surg 2009;250:842848.

10. Fretland AA, Kazaryan AM, Bjornbeth BA, Flatmanrk K, Andersen MH, Tonnessen TI, Bjornelv GMW Fagerland MW, Kristiansen R, Oyri K, Edwin B. Open versus laparoscopic liver resection for colorectal liver metastases (the Oslo-CoMet study): study protocol for a randomized controlled trial. Trials 2015;16:73.

11. Huh JW, Koh YS, Kim HR, Cho CK, Kim YJ. Comparison of laparoscopic and open colorectal resections for patients undergoing simultaneous R0 resection for liver metastases Surg Endosc 2011;25:193-198.

12. Akiyoshi T, Kuroyanagi H, Saiura A, Fujimoto Y, Koga R, Konishi T, et al. Simultaneous resection of colorectal cancer and synchronous liver metastases: initial experience of laparoscopy for colorectal cancer resection Dis Surg 2009;26:471-475.

13. Bretagnol F, Hatwell C, Farges O, Alves A, Belghiti J, Panis Y. Benefit of laparoscopy for rectal resection in patients operated simultaneously for synchronous liver metastases: preliminary experience. Surgery 2008;144:436-441.

14. Hu M, Ou-yang C, Shao G, Xu D, Liu R. Outcomes of open versus laparoscopic procedure for synchronous radical resection of liver metastatic colorectal cancer: a comparative study Surg Laparosc Endosc Percutal Tech 2012;22:364-369.

15. Altuntas TE, Unel S, Gezen FC, Aksakal N, Civil O, Vural S, Ozates M, Oncel M. Stereotactic excision of additional lesions detected with intraoperative ultasound examination during radiofrequency dissecting sealar (Habib) assisted hepatic metastasectomy: report of 4 cases. Indian J Surg 2014;76:61-65. 